\title{
The impact of using theZingiber officinale extract in controlling the endogenous bacterial contamination of date palm during tissue cultures.
}

\author{
El-Dawayati Maiada M. ${ }^{1}$, Zayed Zeinab E. ${ }^{2} *$ and Farrag Hala M. ${ }^{3}$
}

Biotechnology Department, The Central Lab of Date Palm Researches and Development (CLDPRD)- Agriculture Research Center (ARC), Giza, Egypt.

*Corresponding Address

\begin{abstract}
Endogenous bacterial infections are the most critical problem hampers date palm (Phoenix dactylifera) micropropagation cycle. This work aimed to evaluate the influence of the antibacterial property of ginger(Zingiber officinale) extract on suppressing the endogenous bacterial contamination of date palm tissuecultures, to avoid the continuous using of the ordinary chemical antibiotic. The prepared aqueous extract ofZingiberofficinaleat different concentrations $(0.5,1,2,4,6,8$, or $10 \mathrm{ml} / \mathrm{l})$, in comparison toantibiotic, Chloramphenicol or Tetracycline at $100 \mathrm{mg} / \mathrm{l}$, studied onmultiplication media of Gondelah cultivar.The residual effect of all studied treatments also followed up on the rooting media. The results showed that the concentrations of ginger extract at 8 or $10 \mathrm{ml} /$ (without significant result between) came in the second rank follow the Tetracycline in inhibition the growth of the endogenous bacterial contamination of shoot clusters during the multiplication stage, but subsequently, their residual effect during the rooting stage recorded the highest significant results over the use of antibiotics in preventing bacterial growth in plantlets' cultures. Ginger extract at 8 or $10 \mathrm{ml} / \mathrm{l}$ gave the highest significant results of the vegetative growth of shoot clusters explants on multiplication media, as well as, the highest values of plantlets vegetative growth during the rooting stage. So, using the ginger extract as an organic antibacterial source for controlling the endogenous bacterial problem of the date palmensures that cultures are controlled protective, well vegetative growth, and avoiding the disadvantages of the continuously using of ordinary antibiotics.
\end{abstract}

Keywords- Antibiotics, Ginger extract, Endogenous bacterial contamination, Phoenix dactylifera, Micropropagation.

\section{INTRODUCTION}

Date palm (Phoenix dactylifera L.) is a perennial tree, represents an essential fruit crop around the countries of the Middle East and North Africa. It possesses a great economic importance and has an obvious role in socioeconomic life in these countries. (El Hadrami and AlKhayri, 2012). Because of all constraints associated with conventional date palm propagation using seeds or offshoots, in vitro culture has become attractive and alternative for mass propagation of commercial cultivars. This technique allows the rapid multiplication of healthy and true- to- type date palm planting materials (Al-Samir et al., 2015).Microbial contamination by fungi or bacteria, is one of the most obstacles hinder the date palm tissue culture process, which can destroy almost cultures in any stage during micro propagation protocols (Odutayo et al., 2007;Abass, 2013). Date palm Bacterial contamination may result from the plant explants materials, the surrounding environment of the laboratory, operators' performance, or inadequate sterilization processes, resulted in reduce growth rate and increase culture mortality (Mbah and Wakil, 2012). Date palm micro propagated cultures are occasionally highly contaminated with, endogenous bacteria, even well-sterilized cultured explants remain with them these contaminants during the in vitro cycle (Abahmane, 2017). In this respect, 
endogenous(endophytic) bacterial contamination caused serious problems in micro propagation protocols of various plants species such as banana(Oliveira et al., 2016), yam (Wakil and, Mbah, 2012), prunes (Quambusch et al., 2014) strawberry (Taghizadeh et al., 2016) and grapevine (Thomas et al., 2017).Generally, these endogenous contaminants are not easily eliminated by the action of surface disinfectants, due to their location inside cell tissues. Endophytic bacterial contamination is remaining latent during in vitro growth and they expected to attack suddenly in any stage on plant cultures media (Cassells, 2012). The great distinctions of both gramnegative and gram-positive endogenous bacteria have been explored in date palm tissues. Mainly, genus Bacillus is a dominant group, with four species (B. subtilis, B. safensis, $B$. cereus and B. sonorensis), Enterobacteriaceae, and other isolates that belonged to Achromobacter, Acinetobacter, Serratia and Pseudomonas species. (Siala et al., 2016).Different antibiotics sources i.e., Nystatin, Streptomycin Gentamicin, Amoxicillin, Chloramphenicol and tetracycline reused to restrain bacterial infection inside in vitro date palm cultures. (Al-Kaby 2004; Al-Dosary et al., 2011; Abass et al., 2016;Abahmane, 2017). However, antibiotics may lose their efficiency for many reasons as the bacteria resistance because of repeatedly use infrequently subcultures. Moreover, phytotoxicity or poor penetration into plant tissues were serious adverse of using antibiotics (Mbah and Wakil, 2012).

Plant-derived compounds illustrate an untapped source of secure, influential, and environmentally opportune antimicrobial. The essential role of some plant extracts as an antibacterial activity is referring to the existent of some bioactive compounds as secondary metabolites in the plant cells (Taghizadeh et al., 2016).At this point many studies determined plant extracts as an organic and safe source for anti-bacterial activity as betel (Hoque et al., 2011), ginger (Kamazeri et al., 2012), Hindi clove (Joshi et al., 2011), Lavender (Hui et al., 2010), lemon (Kirbaslar et al., 2009), and turmeric (Allawi et al., 2009).Ginger is an aromatic herb, that literature has well-reviewed, about its antimicrobial activity against many pathogenic
species(Sendanayake et al., 2017). There are little reports about using plant extract against endophytic bacterial contamination of in vitro plant cultures. The current study mainly aimed to evaluate the effect of ginger extract as an organic antibacterial source for controlling the endogenous bacterial contamination of date palm tissue cultures in comparison to the antibiotics Chloramphenicol or Tetracycline,to reduce the disadvantages of repeating antibiotic application. Healthy and well full rooted, plantlets, are the main point to achieve successful transferring to the acclimatization stage. Aqueous extract of Ginger was tested on the in vitro established, clean shoot cultures of date palm cultivar Gondelah., at different concentrations, supplemented in basic nutrient MS media formulation for three frequently subcultures of multiplication stage and the residual effect during the rooting stage is also studied. Common antibiotics such as Chloramphenicol or Tetracycline and control treatments used as a comparative study to evaluate the antibacterial efficiency of Ginger extract.

\section{MATERIALS AND METHODS}

This study conducted at the biotechnology department, of the Central Lab for Date Palm Researches and Development- Agricultural Research Center, Giza, Egypt. Date palm offshoots, of Gondelah cultivar were brought from, Aswan, Governorate, to use as starting shoot tips explants. For the micropropagation protocol, sterilization and, establishment steps followed as recommended by(EIDawayati and Zayed, 2017).

Plant Material: -Shoot cultures (2-3 cm length), taken at the multiplication stage during micro propagation cycle, wereused as a source of explants(each cluster consists of 34 shootlets). All shoot cultures were checked carefully for any existing light or heavy signs of endogenous bacterial colonies contamination.

Shoot cultures contaminated by endophytic bacteria were determined by, white or creamy colonies, with a cloudy appearance on the surface of the culture medium. Fig (1) and any suspicious cultures were discarded. 


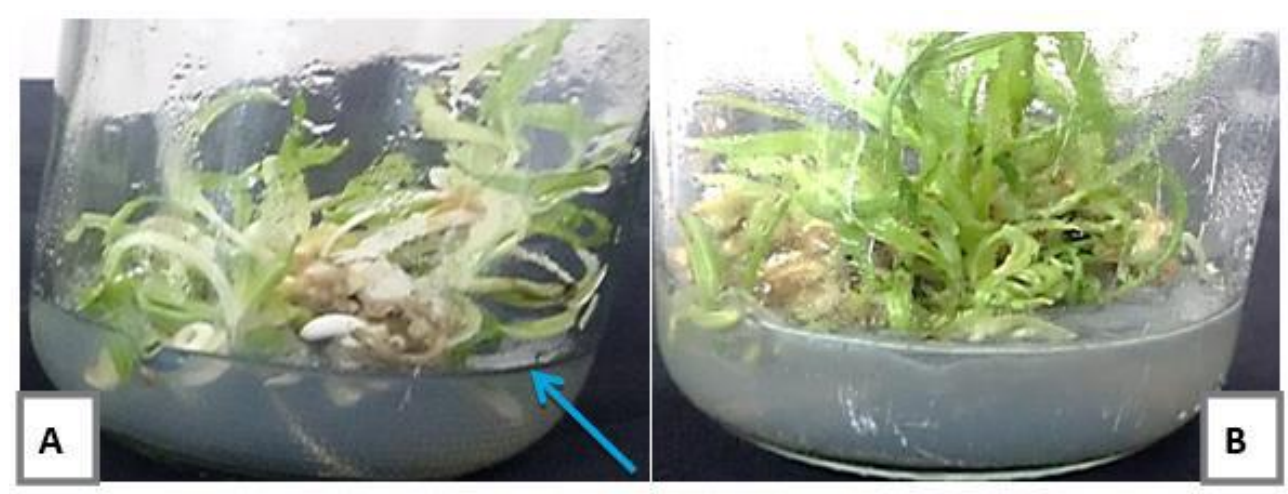

Fig.1: (A) Beginning of appearance of endogenous bacterial contamination associated with shoot culture of the date palm.

(B) A high degree of cloudy appearanceof endogenous bacterial contamination in shoot cultureof the date palm.

\section{The preparation of ginger extract: -}

Fresh ginger rhizomes were washed with tap water, then peeled and chopped in slides, by a sterile knife. About 100 gm of fresh Ginger left at room temperature for 2-3 h., then oven-dried at $35-40^{\circ} \mathrm{C}$ for $24 \mathrm{~h}$. After drying the amount equal to 15 gmand $190 \mathrm{ml}$ of sterile water was added to the dried weight and equated to $200 \mathrm{ml}$ in total, then boiled it on direct flame for 5-10minutes, and it left for $1 \mathrm{hr}$. Then, filtration by sterile gauze. Extraction for the residue from the filtration was repeated twice. The liquid filtrates combined and saved in a sterile cap glass bottle, under storage conditions at $4-6^{\circ} \mathrm{C}($ Sabra et al.,2014).

Effect of ginger extract on contamination during multiplication: - Clean shoot clusters(free of any contamination source)were transferred and inoculated on fresh multiplication nutrient media in three groups as follows: - the first group was contained media without any addition of antibiotics or antibacterial agent(control treatment). The second group was contained media with the addition of ordinary antibiotics Chloramphenicol or Tetracycline at $100 \mathrm{mg} / \mathrm{L}$ for each. The third group was contained multiplication nutrient media with the addition of different concentrations of Ginger extract at $(0.5,1,2,4$, 6,8 , or $10 \mathrm{ml} / \mathrm{L}$ ). Multiplication nutrient media composed of 3/4strength of MS (Murashig and Skoog 1962) basal salts, (MS) vitamins, $40 \mathrm{~g}$ sucrose, $0.4 \mathrm{mg} / \mathrm{l}$ Thimine-Hcl, $100 \mathrm{mg} / \mathrm{L}$ Myo-inositol, $0.1 \mathrm{mg} / \mathrm{L}$ biotin, $0.5 \mathrm{mg} / \mathrm{L}$ Pyridoxine, $0.5 \mathrm{mg} / \mathrm{L}$ nicotinic acid, 170 $\mathrm{mg} / \mathrm{LNaH}_{2} \mathrm{PO}_{4}$ and supplemented with plant growth regulator $0.05 \mathrm{mg} / \mathrm{LB}$ enzyladenine $(\mathrm{BA})$ and $0.1 \mathrm{mg} / \mathrm{L}$ Naphthaleneacetic acid (NAA). Each treatment was contained 30 jars, and each jar contains 3 explants. All groups of cultured jars were incubated under the light condition with 1500 lux for 16 (hrs.) and 8(hrs.) dark at 27 $\pm 2{ }^{\circ} \mathrm{C}$. The cultures were maintained by regular subcultures on fresh medium 3 times, with 8 weeks intervals. Data were taken daily about the appearance degree of endogenous bacteria in the cheeked cultures jars, contaminated cultures by endophytic bacteria were determined as mentioned above. At the end of each subculture, vegetative growth performance recorded for uncontaminated cultures jars (free of endogenous bacterial contamination), as follows: - the average of shoot number, shoot length $(\mathrm{cm})$, secondary embryos number, and growth vigor degree. The data representing 'degree' were scored visually, as $1=$ no change; $2=$ below average; 3 = above average; 4 = high, following the recommendation of ElDawayati et al., (2018).

Effect of the residual effect of ginger extract on contamination during rooting: -At the end of multiplication stage, elongated plantlets $(10 \mathrm{~cm})$ were collected from all previous treatments of the three groups cultures, and transferred to rooting nutrient media which composed of the same components of multiplication nutrient medium but containing in addition of $1 \mathrm{~g} / \mathrm{L}$ Activated charcoal and supplemented with $1 \mathrm{mg} / \mathrm{L}$ (NAA) and $1 \mathrm{mg} / \mathrm{L}$ Indole butyric acid (IBA) as plant growth regulators. The cultures were maintained by the regular subculture on fresh medium for tow subcultures (with 8 weeks intervals), in order to follow up the residual effect of the two types of ordinary antibiotics (Chloramphenicol and Tetracycline at $100 \mathrm{mg} / \mathrm{L})$ compared to different concentrations of ginger extract on the appearance of endogenous bacteria and the growth development, during rooting stag. Each treatment presented in 30 jars and each jar contains 3 explants. All groups of cultured jars were incubated under the light condition, with 3000 lux, for 16 (hrs.) and 8 (hrs.) dark at $27 \pm 2^{\circ} \mathrm{C}$. Data were taken about the appearance degree of endogenous bacteria inthe cheeked cultures jars. The vegetative growth performance 
also recorded for uncontaminated cultures jars (free of endogenous bacterial contamination), as the average of shoot length $(\mathrm{cm})$, root number, and root length $(\mathrm{cm})$.

For all prepared media $\mathrm{pH}$ was adjusted to $5.7 \pm 0.1$ before adding agar at $6 \mathrm{~g} / \mathrm{l}$ and medium dispensed at $(40 \mathrm{ml} / \mathrm{jar})$ into small jars $(150 \mathrm{ml})$ for multiplication media, or into (250 $\mathrm{ml} / \mathrm{jars}$ ) for rooting media before autoclaving at $121^{\circ} \mathrm{C}$ and $15 \mathrm{Ibs} / \mathrm{in} 2$ for $20 \mathrm{~min}$. At the end of the experiments, all received healthy full rooted plantlets from all treatments transferred to the acclimatization stage.

Statistical analysis: -The analytical statics was performed in a complete randomized design with three replicates. All obtained results were determined by subjection to statistical analysis of variance, according to the method described by Snedecor and Cochran (1982)using the LSD test at $5 \%$.

\section{RESULTS}

Obtained data for the endogenous bacterial appearance degree and the vegetative development of explant cultures during multiplication and rooting stages,under different concentrations of ginger extract at $(0.5,1,2,4,6,8$, or 10 $\mathrm{ml} / \mathrm{L}$ ), or two ordinary antibiotics (Chloramphenicol or Tetracycline at $100 \mathrm{mg} / \mathrm{L}$ ), incorporated in cultures media of date palm shoot clusters explants, revealed as follows: -

Obviously, from data, of Fig (2), untreated shoot cultures media group (control treatment) showed the highest significant value of endogenous bacteria appearance for three subcultures. Shoot cultures media group which treated with Tetracycline antibiotic for three subcultures recorded the lowest significant value for endophytic bacteria appearance. There was no significant difference between using ginger extract at $10 \mathrm{ml}$ or $8 \mathrm{ml}$ for controlling the endogenous bacteria appearance in shoot cultures media, which they ranked significantly after Tetracycline antibiotic treatment for suppressing endophytic bacterial contamination growth. Shoot cultures media which treated with ginger extract at $10 \mathrm{ml}$ showed significantly less degree of endogenous bacteria appearance, to be more antimicrobial activity than using Chloramphenicol antibiotic. Data obtained revealed that by increasing ginger extract concentrations in shoot cultures media the inhibition of endophytic bacteria appearance increase significantly comparing to control treatment.

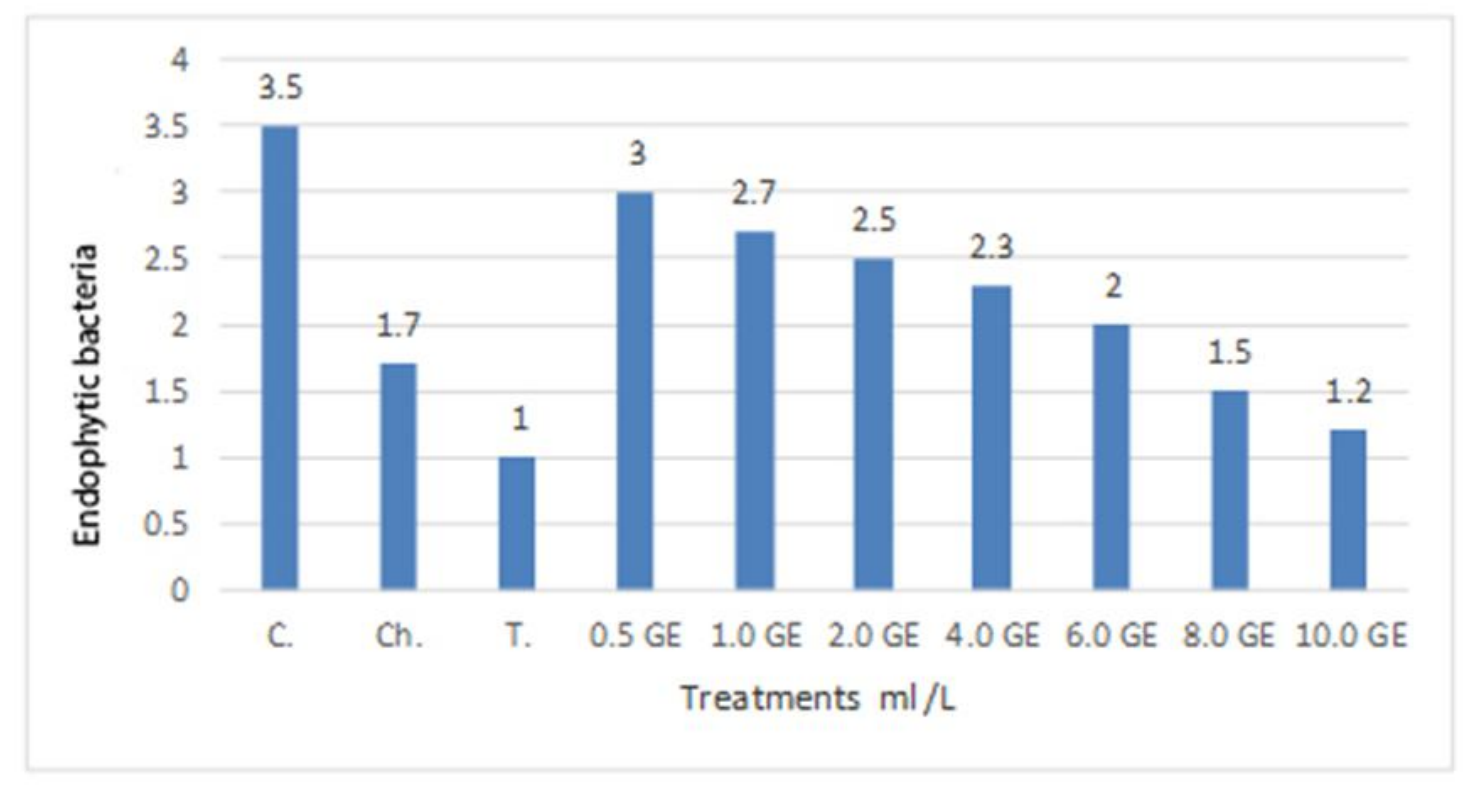

Fig.2: Effect of two types of ordinary antibiotics Chloramphenicol (Ch) or Tetracycline (T) at 100mg/L compared to different concentrations of ginger extract $(G E)$ on the appearance of endogenous bacteria in shoot cultures of date palm cv.

Gondelah during the multiplication stage. 
Table 1.Effect of two types of ordinary antibiotics (Chloramphenicol and Tetracycline at 100mg/L) Compared to different concentrations of ginger extract on vegetative growth of date palm $\mathrm{cv}$. Gondelah during the multiplication stage.

\begin{tabular}{|l|l|l|l|l|l|}
\hline \multirow{2}{*}{ Treatments } & Avg. shoot no. & $\begin{array}{l}\text { Avg. shoot length } \\
(\mathrm{cm})\end{array}$ & $\begin{array}{l}\text { Avg. sec.embryo } \\
\text { no. }\end{array}$ & Growth vigor \\
\hline Control & 31.30 & 6.21 & 20.11 & 3.33 \\
\hline \multirow{2}{*}{$\begin{array}{l}\text { Antibiotic types } \\
100 \mathrm{mg} / \mathrm{L}\end{array}$} & Chloramphenicol & 32.31 & 5.55 & 18.78 & 2.88 \\
\cline { 2 - 6 } & Tetracycline & 32.72 & 5.73 & 19.00 & 2.88 \\
\hline \multirow{4}{*}{ Ginger extracts } & $0.5 \mathrm{ml}$ & 32.90 & 6.33 & 23.34 & 3.55 \\
\cline { 2 - 6 } & $1.0 \mathrm{ml}$ & 34.70 & 6.94 & 26.36 & 3.55 \\
\cline { 2 - 6 } & $2.0 \mathrm{ml}$ & 35.71 & 6.94 & 29.22 & 3.77 \\
\cline { 2 - 6 } & $4.0 \mathrm{ml}$ & 37.10 & 7.15 & 33.35 & 4.00 \\
\cline { 2 - 6 } & $6.0 \mathrm{ml}$ & 39.71 & 7.63 & 34.71 & 4.66 \\
\cline { 2 - 6 } & $8.0 \mathrm{ml}$ & 42.31 & 8.51 & 36.66 & 4.88 \\
\cline { 2 - 6 } & $10.0 \mathrm{ml}$ & 43.55 & 8.53 & 36.72 & 4.88 \\
\hline LSDat0.05 & 3.33 & 0.51 & 5.20 & 0.55 \\
\hline
\end{tabular}

Observation from Table (1) showed that maximum values of the average of shoot number shoot length, secondary embryo number and the growth vigor degree obtained with ginger extract treatments at $8 \mathrm{ml}$ and $10 \mathrm{ml}$, without significant differences between them. Where the lowest significant results of the average of shoot number of date palm shoot cultures obtained on control media treatment, culture media supplemented with both of (Chloramphenicol or Tetracycline at $100 \mathrm{mg} / \mathrm{L}$ ) antibiotics treatments and culture media supplemented with ginger extract treatment at $0.5 \mathrm{ml}$ treatment, without significant differences among them. Data indicated that the average of shoot length and growth vigor degree of shoot cultures increased significantly by increasing the ginger extract concentration, from $4 \mathrm{ml}$ to $10 \mathrm{ml}$, comparing to control media treatment and, both of (Chloramphenicol or Tetracycline at $100 \mathrm{mg} / \mathrm{L}$ ). The addition of ginger extract at $8 \mathrm{ml}$ or $10 \mathrm{ml}$ to shoot cultures media, during multiplication stage, gave a great positive effect on the vegetative growth parameters, compared to the addition of ordinary antibiotics (Chloramphenicol or Tetracycline at $100 \mathrm{mg} / \mathrm{L}$ ).

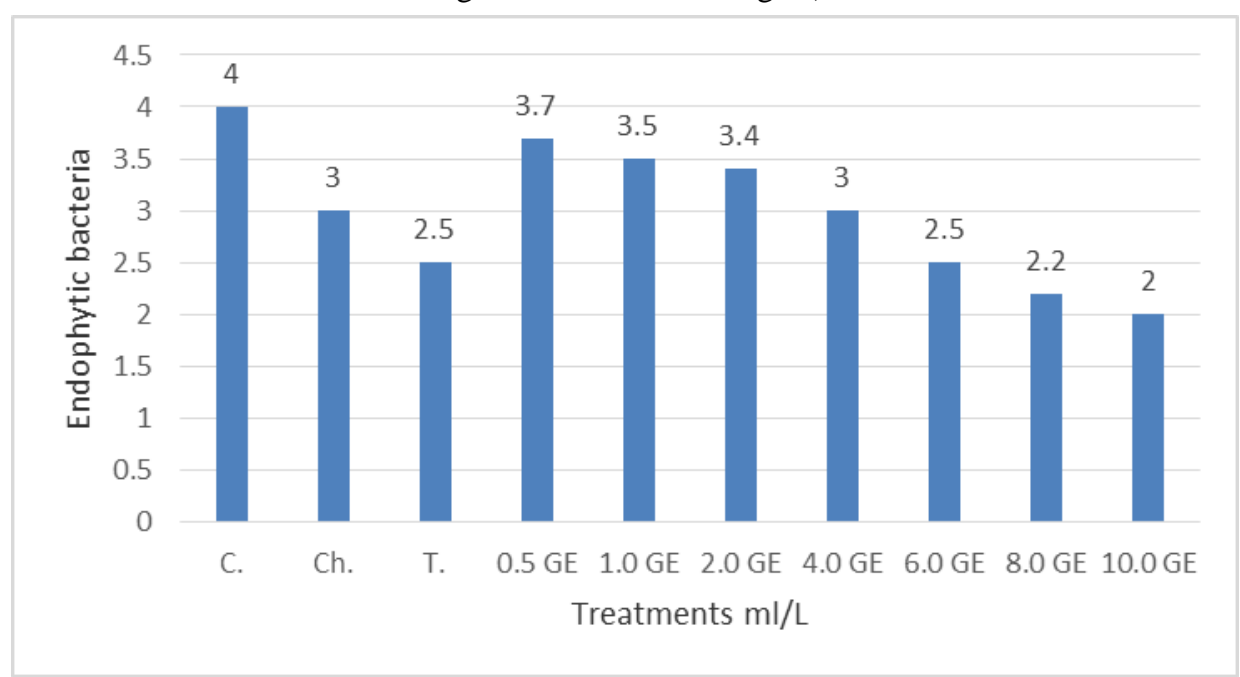

Fig.3: The residual effect of two types of ordinary antibiotics (Ch) Chloramphenicol and (T) Tetracycline at 100mg/L) compared to different concentrations of $(G E)$ ginger extract on endogenous bacteria appearance of date palm cv. Gondelah cultures during the rooting stage. 
Data in Fig (3) revealed that the highest degree of endogenous bacterial contamination appearance recorded with control treatment. The lowest significant results for endophytic bacteria appearance degree on plantlets cultures achieved when these plantlets cultures developed on multiplication media, whish supplemented with high concentrations of ginger extract at 8 and $10 \mathrm{ml}$, without significant differences in between. Where the residual effect of using a common antibiotic (Chloramphenicol or Tetracycline) on controlling endophytic bacterial contamination appearance degree during the rooting stage, were ranked significantly in the second order. The residual effect of using Tetracycline treatment was more effective significantly than the residual effect of using Chloramphenicol treatment in suppressing bacterial contamination growth. On the other hand explants, cultures received from multiplication cultures supplemented with a low concentration of ginger extract at $0.5 \mathrm{ml}$, hadn't inhibited endophytic bacterial contamination as a residual effect during the rooting stage, without significant difference with control treatment result. It seemed to be that, with the increasing of ginger extract concentrations in cultures media during the multiplication stage, endophytic bacterial contamination gradually showed decreasing in bacteria appearance as residual effects during the rooting stage.

Table. 2 The residual effect of two types of ordinary antibiotics (Chloramphenicol and Tetracycline at 100mg/ L) compared to different concentrations of ginger extract on vegetative growth of date palm cv. Gondelah cultures during the rooting stage.

\begin{tabular}{|l|l|l|l|l|}
\hline \multicolumn{2}{|c|}{ Treatments } & $\begin{array}{c}\text { Avg. plantlet } \\
\text { length }(\mathbf{c m})\end{array}$ & Avg. root no. & $\begin{array}{c}\text { Avg. root } \\
\text { length(cm) }\end{array}$ \\
\hline Control & Chloramphenicol & 14.6 & 5.6 & 4.7 \\
\cline { 2 - 5 } $\begin{array}{l}\text { Antibiotic types } \\
100 \mathrm{mg} / \mathrm{L}\end{array}$ & Tetracycline & 14.2 & 5.2 & 4.5 \\
\hline \multirow{5}{*}{ Ginger extracts } & $0.5 \mathrm{ml}$ & 14.6 & 5.7 & 4.7 \\
\cline { 2 - 6 } & $1.0 \mathrm{ml}$ & 14.8 & 6.6 & 5.2 \\
\cline { 2 - 6 } & $2.0 \mathrm{ml}$ & 15.0 & 6.9 & 5.5 \\
\cline { 2 - 6 } & $4.0 \mathrm{ml}$ & 16.3 & 7.6 & 5.5 \\
\cline { 2 - 6 } & $6.0 \mathrm{ml}$ & 16.6 & 8.3 & 5.5 \\
\cline { 2 - 6 } & $8.0 \mathrm{ml}$ & 17.5 & 8.6 & 5.7 \\
\cline { 2 - 5 } & $10.0 \mathrm{ml}$ & 17.7 & 8.0 & 5.9 \\
\hline \multirow{2}{*}{ LSDat0.05 } & 0.52 & 1.90 & 1.65 \\
\hline
\end{tabular}

From data in Table (2) obtained results showed that the highest values of plantlets length and roots number/plantlets during the rooting stage recorded after using ginger extract at $8 \mathrm{ml}$ or $10 \mathrm{ml}$ as an antibacterial agent to control the endophytic appearance, during multiplication stage. Received plantlets from shoot cultures treated with ordinary antibiotic Chloramphenicol, Tetracycline at $100 \mathrm{mg} / \mathrm{L}$ or control treatment gave the lowest results in increasing of plantlets length and root number/plantlets, during the rooting stage as a residual effect. It could be noted that all plantlets received from 8 $\mathrm{ml}$ and $10 \mathrm{ml}$ as best treatments for controlling endogenous bacterial contamination of multiplied shoots cultures, could resume their development successfully for further acclimatization stage Fig (4). 


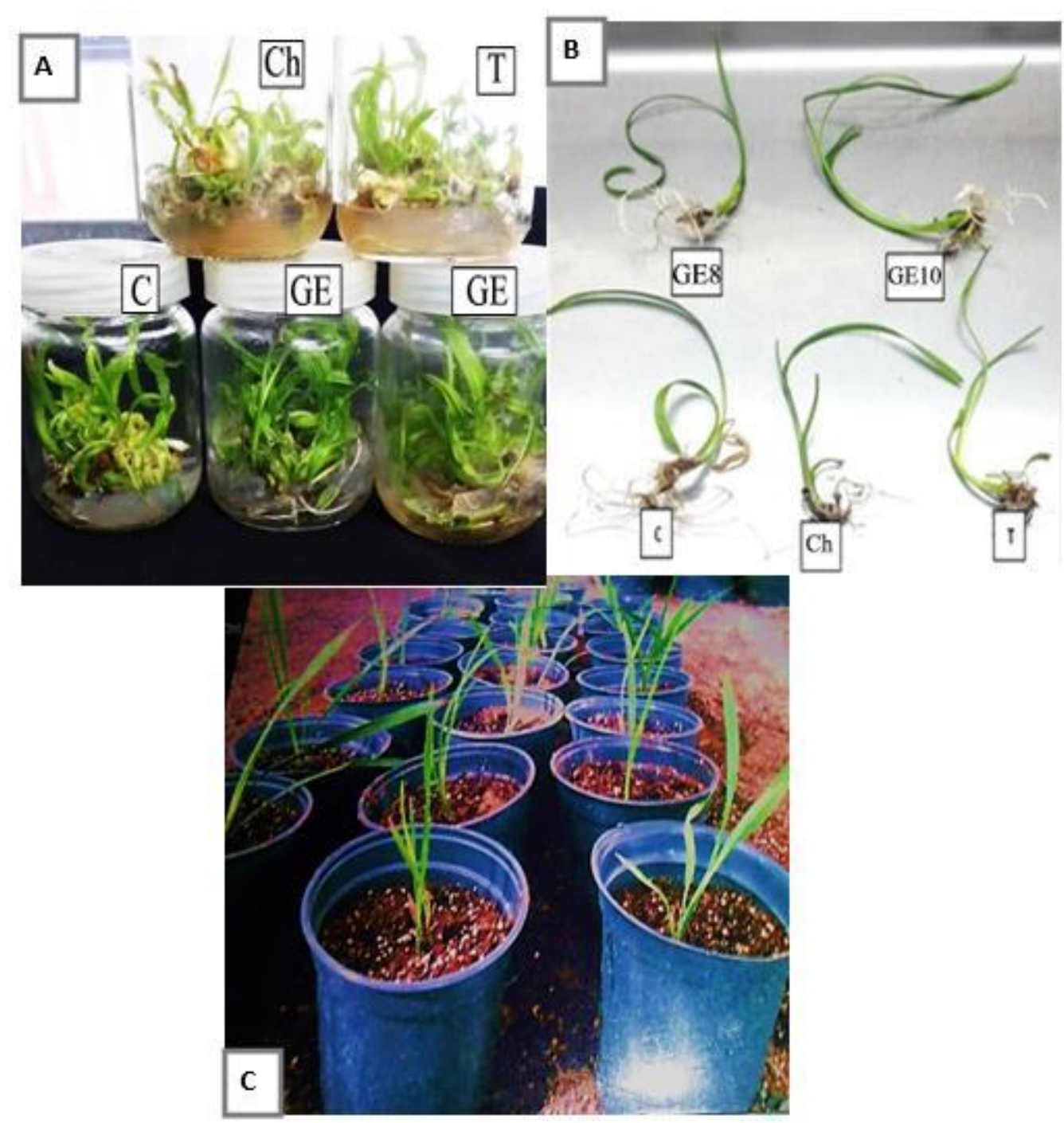

Fig.4: A) The addition of ginger extract (GE) at $8 \mathrm{ml}$ or at $10 \mathrm{ml}$ as antibacterial agent have a great effect on the vegetative growth parameters comparing to the addition of ordinary antibiotics (Ch) Chloramphenicol or $(T)$ Tetracycline and $(C)$ control, during multiplication stage of shoot cultures of date palm cv. Gondelah.B)Full intact Plantlets obtained from ginger $(G E)$ treatments at $8 \mathrm{ml}$ or $10 \mathrm{ml}$ comparing to antibiotics $(\mathrm{Ch})$ Chloramphenicol or $(T)$ Tetracycline at $100 \mathrm{mg} / \mathrm{L})$ and $(C)$ control treatments. C)Healthy and well-developed plantlets from ginger treatments at $8 \mathrm{ml}$ or $10 \mathrm{ml}$, transferred successfully tothe acclimatization stage.

\section{DISCUSSION}

Endogenous or endophytic bacterial contamination is a serious problem in date palm tissue cultures due to competition for nutrients, the release of toxins and overgrowth of plant tissue which could destroy the whole propagation process. This source of contamination in date palm tissue culture is not extensively studied spot. It could be suggested that these endophytic bacteria can remain undetected due to some conditions which are not optimal for their growth, such as the composition of the culture medium of the nutrient elements concentrations, the carbon source concentration, the $\mathrm{pH}$ of the growth culture medium, or the surrounded temperature (Odutayo et al., ISSN: 2456-1878
2007). On the other hand, Cassells (2012) reported that infection maystay implicit within callus tissue for more than eight months, and reached to a year within shoot cultures, without causing any visible symptoms in contaminated cultures. When the surrounded growth conditions of cultures changed throughout subcultures transferring, endogenously bacterial contaminants, which attend in small numbers, can rapidly, increase and harm the plant cultures (Leifert, 2000). There are recent opinions about the capabilities of the influential natural antimicrobial compounds derived originally from plants that contain a broad set of secondary metabolites such as alkaloids, tannins, flavonoids, glycosides, quinones, which 
are considered beneficial as a substitution to antibiotics. (Savoia, 2012, Compean, and Ynalvez, 2014).Hydrophobicity is a significant feature, for plant extracts and their ingredients, which qualify them to split the lipids of the bacterial cell membrane and mitochondria, troubling the whole-cell construction, and causing more cell permeability (Taghizadeh et al.,2016). In this regard, antimicrobial property and phytochemical contents of ginger were reviewed by many types of research(Ali et al., 2008; Sendanayake, 2017).

The obtained results of this study revealed that ginger extract at $10 \mathrm{ml} / \mathrm{l}$ showed significantly less value of endophytic bacteria appearance in shoot cultures of date palm cv. Gondelah, than those treated with Chloramphenicol antibiotic. This is on the other side of Abass et al.,(2016) who found thatboth Gentamicin and Chloramphenicol showed, high defense performance for date palm callus culture. However, Sabra et al., (2014)mentioned that antimicrobial activity of ginger rhizomes extract, versus both bacterial isolates of Grampositive and Gram-negative, refers that chemical components of extract may responsible for a disturbance of the membrane and/or genetic structure of the isolates. The antimicrobial activity of ginger may be owing to the considerable quantity of phenols as gingerol paradol, shogaols and zingerone (Rahmani et al., 2014).Beside also the existent of flavonoids in ginger, which found to be affective as in vitro antimicrobial substances, against an ample range of microorganisms (Fullerton et al.,2011). At this point, Dina and Hussein (2017) reported that, highest amount of total phenolic and flavonoids were detected in extract of both ginger and cinnamon. This was confirmed by Miklasińska-Majdanik(2018) who reported that,the increase in the number of hydroxyl groups presented on the phenolic ring, leading tohydroxylation property of plant extracts, that resulted in the increasing in the antimicrobial activity. These findings may explain the antimicrobial activity of ginger extract.

From our results, it could be noted that shoot cultures group treated with Tetracycline antibiotic at $100 \mathrm{mg} / \mathrm{L}$ for three subcultures recorded the lowest significant value for endophytic bacteria appearance during multiplication stage, but less and weak vegetative growth were observed. This is confirmed by Khafagi et al., (2001)who reported that antibiotics are currently used but are not always effective, can alter plant growth, and are costly, and resistant strains can result in extensive use. However, it has to be taken into consideration the phytotoxicity of some antibiotics(Oliveira and Scherwinski-Pereira, 2016).

Thus antibiotics should be restricted to very limited culture stages. Prolonged exposure to Tetracycline or ISSN: 2456-1878
Chloramphenicol at $100 \mathrm{mg} / \mathrm{L}$ adversely affected shoot formation. The same result was obtained with shoots of Pelargonium cultures grown in the presence of cefotaxime antibiotic for long periodshowed a low rate of shoot formation, shorter and pale, shoots, finally caused the end of cultures by death (Wojtania et al., 2005). Growth value and plant shape followed up to check whether using antibiotics or ginger extracts, led to phytotoxicity on the later plantlet's growth. From resultsit could be observed that the residual effect of using Tetracycline or Chloramphenicol antibiotics treatment on controlling endophytic bacterial contamination appearance degree during rooting stage, came at the second rank significantly after using ginger treatment at $8 \mathrm{ml}$ or $10 \mathrm{ml}$, which showed superiority in suppressing the endophytic bacterial growth during rooting stage as residual effect for being used as antibacterial agent during multiplication stage. This was contrary to Cassells (2012), who reported that bacterial growth is only repressed by antimicrobial curing and when chemical compounds are stopped to using, the bacteria colonies recapture their growth. In general ginger extract addition at $8 \mathrm{ml}$ or $10 \mathrm{ml}$ to date palm cultures during multiplication stage and also their residual effect during the rooting stage showed well enhancement for vegetative growth and plantlets development, this may be due to the nutrition value of Ginger rhizome contents of fats, carbohydrates, vitamins, minerals, proteins, vitamins and minerals as sodium and calcium as reported by (Kumar et al., 2011; Sendanayake et al., 2017).

\section{CONCLUSION}

Under the light of the presented study, the antibacterial potential of ginger aqueous extract was investigated as a primary study. Satisfying results obtained from studied concentrations at $8 \mathrm{ml} / \mathrm{L}$ and $10 \mathrm{ml} / \mathrm{L}$ to eliminate endophytic bacterial contamination attack during the multiplication stage and their residual effects were resumed during the rooting stage. Moreover, well development and good vegetative growth of received plantlets were obtained. These results can be a diver to limit the repeated use of antibiotics. Therefore, more studies with ginger extract antibacterial potential can be carried out. Also, studies of using other plant extracts and phytochemicals sources of defined antimicrobial properties would have a great significance in date palm tissue culture, to eliminate or control microbial contamination and to restrict using antibiotics. Characterize and identify of date palmassociated bacteria which lead to more successful antibacterial therapies, intensive studies in this concern are needed. The lack of descriptive information and antibiotic susceptibilities of a large number of date palm endophytic 
bacteria further complicate the use of antibiotics. The ultimate goal for in vitro propagation is obtaining plantlets free off any microbial contamination.

\section{ACKNOWLEDGMENTS}

The authors are thankful to the Central Laboratory of Date Palm Researches and Development, Agriculture Research Center, Giza, Egypt, for providing research facilities. Special thanks delivered to Dr. Mahmoud Ali a researcher at, our laboratory, for his eminent help in this study. We further are grateful to the reviewers and the editor for their valuable comments and opinions on the research paper.

\section{REFERENCES}

[1] Abahmane L., 2017.Cultivar-dependent direct organogenesis of date palm from shoot tip explants, pp. 3-15.In J. M. AlKhayri et al., (eds.), Date palm biotechnology protocols,vol. I.Springer, New York, USA.

[2] Abass M.H., 2013. Microbial contaminants of date palm (Phoenix dactylifera L.) in Iraqi tissue culture laboratories. Emirates J. Food Agr. 25: 875-882.

[3] Abass M.H., Al-Utbi S.D.,Al-Samire E.A., 2016. Morphological and biochemical impact of different decontamination agents on date palm (Phoenix dactylifera L.) procallus. Australian J. C. S. 10:1022-1029.

[4] Al-DosaryN.H., Al-Mussawi M.A.,Al-Taha H.A., 2011. Isolation and identification of bacterial types that cause contamination of date palm (Phoenix dactylifera L.) callus and studying the inhibition activities of some plant extracts and antibiotics. Basra J. Date Palm Res. 10: 68-81.

[5] Ali B.H., Blunden G., Tanira M.O.,Nemmar A., 2008. Some phytochemical, pharmacological and toxicological properties of ginger (Zingiberofficinale Roscoe). Food Chem. Toxico. 46: 409-420.

[6] Al-Kaby A.M., 2004. The effect of some antibiotics and fungicides on the growth of embryogenic callus of date palm (Phoenix dactylifera L.). Basra J Date Palm Res. 3: 97-110.

[7] Allawi S.S., Auda J.M., Hameed H.Q.,Ali T.I., 2009. The effect of Curcuma longa (turmeric) rhizomes extracts on pathogenic bacteria in comparison with standard antibiotics. J. Biotechnol. Res. C. 3: 15-20.

[8] Al-SamirE.A., Al-Utbi S.D.,Abass M.H., 2015. Phytotoxic effect of 2,4-D and dicamba on date palm (Phoenix dactylifera L.) tissue cultures at the initiation stage. A.A.B. Bioflux Soc. 7:96-108.

[9] Cassells A.C., 2012. Pathogen and biological contamination management in plant tissue culture: phytopathogens, in vitro Pathogens, and in vitro pests, pp. 57-80. In: VM. LoyolaVargas and N. Ochoa-Alejo, $3^{\text {th }}$ ed. Plant cell culture protocols methods in molecular Biology. Springer, New York, USA.

[10] Compean, K.L.,Ynalvez, R.A., 2014. Antimicrobial activity of plant secondary metabolites: A review. Research Journal of Medicinal Plants, 8, 204-213.
[11] Dina I.,Hussein R., 2017. Phytochemical screening and nematicidalactivity of cinnamon and gingerextract against root-knot nematode (Meloidogyne incognita) infecting tomato. Egyptian J. Agr. 16: 63- 84.

[12] El-Dawayati M.M.,Zayed Z.E., 2017. Controlling hyperhydricity in date palm in vitro culture by reduced concentration of nitrate nutrients, 175-183. In: J.M. AlKhayri et al., (eds.). Date palm biotechnology protocols,vol. I. Springer, New York, USA.

[13] El-Dawayati M.M., Ghazzawy H.S.,MunirM., 2018. Somatic embryogenesis enhancement of date palm cultivar Sewi using different types of polyamines and glutamine amino acid concentration under invitro solid and liquid media conditions. Int. J.Biosci. 12: 149-159.

[14] El Hadrami A., Al-Khayri J., 2012. socioeconomic and traditional importance of date palm. Emirates J. Food Agric. 24: 371-385.

[15] FullertonM.,Khatiwada J., Johnson J.U., Davis S.,Williams L.L., 2011. Determination of the antimicrobial activity of sorrel Hibiscus sabdariffa on Esherichia coli O157:H7 isolated from food, veterinary, and clinical samples. J. Med. Food. 14: 950-956.

[16] Hoque M.M., Rattila S., Shishir M.A., Bari M.L., InatsuYand Kawamoto S., 2011. Antibacterial activity of ethanol extracts of betel leaf (Piper betle L.) against some foodborne pathogens. BangladeshJ.Microbiol. 28: 58-63.

[17] Hui L., He L., Huan L., Xiaolan L.,Aiguo Z., 2010. Chemical composition of lavender essential oil and its antioxidant activity and inhibition against rhinitis related bacteria. African J. Microbiol. Res. 4: 309-313.

[18] Joshi B., Sah G.P., Basnet B.B., Bhatt M.R., Sharma D., Subedi K., Pandey J.,MallaR., 2011. Phytochemical extraction and antimicrobial properties of different medicinal plants (Ocimum sanctum) tulsi, (Eugenia caryophyllata) clove, (Achyranthesbidentata ) datiwan and (Azadirachtaindica) neem. J. Microbiol. Antimicrob. 3: 1-7.

[19] Kamazeri T.S., Samah O.A., Taher M.,Susanti D.,Qaralleh H., 2012. Antimicrobial activity and essential oils of Curcumaaerugonosa, Curcuma mangga and Zingibercassumunar from Malaysia. Asian Pac. J. Trop. Med. 5: 202-209.

[20] Khafagi I., Dewedar A., Kord M.,Mohammed E., 2001. Identification and antibiotic sensitivity of bacteria occasionally isolated from differentiated and undifferentiated cultures of Sinai medicinal plants. Egyptian J. Biol. 3: pp.67-78.

[21] Kirbaslar F.G., Tavman A., Dulger B.,Turker G., 2009. Antimicrobial activity of Turkish (Citrus peels) oils. Pakistanian J Bot. 41: 3207-3212.

[22] Kumar G., Karthik L.,Rao B., 2011. A review on pharmacological and phytochemical properties of Zingiberofficinale(Roscoe) (Zingiberaceae). J. Phar. Res. 4: 2963-2966.

[23] Leifert C., 2000. Quality assurance systems for plant cell and tissue culture, the problem of latent persistence of bacterial pathogens and Agrobacterium - based transformation vector systems. Acta Hort. 530: 87-91. 
[24] Mbah E.I.,Wakil S.M., 2012. Elimination of bacteria from in vitro yam tissue cultures using antibiotics. J. Plant Pathol. 94: 53-58

[25] Miklasińska-Majdanik M., Kępa M., Wojtyczka, R.D., Idzik, D.,Wąsik, T.J., 2018. Phenolic compounds diminish antibiotic resistance of Staphylococcus Aureus clinical strains. International journal of environmental research and public health, 15, 2321.

[26] MurashigeT.,Skoog F., 1962. A revised medium for rapid growth and bioassays with tobacco cultures. Physiol. Plant. 15:473-496.

[27] Odutayo O.I., Amusa N.A., Okutade O.O.Ogunsanwo Y.R., 2007. Sources of microbial contamination in tissue culture laboratories in Southwestern Nigeria. African. J.Agr. Res.2: 67-72.

[28] Oliveira J.P.,Scherwinski-Pereira J.E., 2016. Biochemical characterization of systemic bacteria in bananas, sensitivity to antibiotics and plant phytotoxicity during shoot proliferation. Acta Sci.Agr. Mar. 38: 193-200.

[29] Rahmani A., Al shabrmi F.,Aly S., 2014. Active ingredients of ginger as potential candidates in the prevention and treatment of diseases via modulation of biological activities. Int. J. Physiol. Pathoph. Pharm. 6: 125-136.

[30] Sabra M.M., Al-Masoudi L.R., Al-Gehani S.H.,Abu-Harbah A.O., 2014. Comparative laboratory study on antimicrobial effects of fresh and dry ginger (Zingiberofficinale), Taif, KSA. J.Env. Sci.Tox. Food Technol. 8: 114-123.

[31] Savoia D., 2012. Plant-derived antimicrobial compounds: Alternatives to antibiotics. Future Microbial. 7: 979-990.

[32] Sendanayake L.R., Sylvester TP, De Silva UH, Dissanayake DR, Daundasekera DCand Sooriyapathirana SS, 2017. Consumer preference, antibacterial activity and genetic diversity of ginger (Zingiber officinale Roscoe) cultivars grown in SriLanka. The J.Agr. Sci. 12: 207-221.

[33] Siala R., Chobba I.B., Vallaeys T., Triki M.A., Jrad M., Cheffi M., Ayedi I., Elleuch A., Nemsi A., Cerqueira F., Gdoura R., Drira N.,Gharsallah N., 2016. Analysis of the cultivable endophytic bacterial diversity in the date palm (Phoenix dactylifera L.) and evaluation of its antagonistic potential against pathogenic fusarium species that cause date palm bayoud disease. J. App. Env. Microbiol. 4: 93-104.

[34] Snedecor G.W., Cochran W.G., 1982. Statistical Methods. 7th Edition, Iowa State Univ. Press, Towa, 511.

[35] Taghizadeh M., Solgi M.,Shahrjerdi I., 2016. Various aspects of essential oils application for pathogens controlling in strawberry in vitro culture. Academia. J.Agr. Res. 4: 667674.

[36] Thomas P., Sekhar A.C.,Shaik S.P., 2017. High taxonomic diversity of cultivation-recalcitrant endophytic bacteria in grapevine field shoots, their in vitro introduction, and unsuspected persistence. Planta. 246: 879-898.

[37] Quambusch M., Pirttilä A.N., Tejesvi M.V., Winkelmann T.,Bartsch M., 2014. Endophytic bacteria in plant tissue culture: differences between easy- and difficult-to-propagate Prunusavium genotypes. Tree Physiolo. 34: 524-533.
[38] Wakil S.M.,Mbah E.I., 2012. Screening antibiotics for the elimination of bacteria from in vitro yam plantlets. A.U. J. T. 16: 7-18.

[39] Wojtania A., Puławska J.,Gabryszewska E., 2005. Identification and elimination of bacterial contaminants from pelargonium tissue cultures. J. Fruit Orn. Plant Res. 13: 101108. 